\title{
TOPIC FRONTING, FOCUS POSITIONING AND THE NATURE OF THE VERB PHRASE IN BASQUE*
}

\section{Sectión 1. Grammatical Preliminaries**}

1. As there will be in this paper a good many Basque sentences used as examples, it will be convenient to start with a number of remarks on the grammatical structure of the language, so as to avoid surrounding each example with lengthy explanations irrelevant to the issue at hand. Although most of what I have to say will be valid for all present-day varieties of Basque, the examples will be taken from the Guipuzcoan dialect, unless a different dialect is expressly mentioned.

To facilitate the pronunciation of the examples, the following hints are offered: Vowels and diphthongs are pronounced as in Spanish. $j$ is a voiceless velar fricative, like Dutch $c b$ or Spanish jota. $s$ and $z$ are both voiceless fricatives. They differ only in the point of articulation. $s$ has an apico-alveolar articulation, and $z$ a dorsoalveolar one. $x$ is a palatal fricative, comparable to English sh. The letter combinations $t s$, $t z$ and $t x$ denote simple phonemes, namely, the affricates corresponding to $s, z$ and $x$, respectively. $l l$ indicates a palatalized $l$. Like in Spanish, there are two $r$-sounds, a strongly trilled one, spelled $r$, and a weak flapped $r$, spelled $r$. Before consonants and in final position, the two sounds do not contrast phonetically, and both are then spelled $r$. Thus, we have aur "child", and aurra "the child" ( $-a$ being the definite article). This is merely an orthographic convention: the $r$ of aur sounds the same as the $r$ of aurra.

\subsection{The Structure of the Noun Phrase}

Basque has a definite article $a$ and an indefinite article bat, which follow the noun. The former is a bound form written together with the preceding noun, while the latter is an independent word meaning "one" (both as a numeral and as an

* In: Frank Jansen (ed.), Studies on Fronting (Lisse, 1978), 81-112.

** I would like to thank my Basque informants, teachers and friends for their constant readiness to give thoughtful answers to my numerous questions about their language. Above all, I gratefully acknowledge the valuable assistance of Professor Dr. Luis Michelena, Dr. Francisco Altuna S.J., Mari-Pilar Lasarte, José Manuel Odriozola and Felipe Yurramendi. Al errors, of course, are mine, and mine alone.

Part of the research for this paper was carried out while I was supported by the Netherlands Organization for the Advancement of Pure Reserach (Z.W.O.), projet No. 39-37.

[ASJU Geh 43, 1998, 183-201] http://www.ehu.es/ojs/index.php/asju 
anaphoric pronoun) written separately. Thus: sendagille "doctor", sendagillea "the doctor", sendagille bat "a doctor" or "one doctor".

Gramatical relations are indicated by postpositions. With the postposition (r)i "to", we have: sendagilleari "to the doctor" and sendagille bati "to a doctor". The plural lacks the $r$ even after a vowel: sendagilleai "to the doctors".

Genitive modifiers (like relative clauses) precede their heads, but adjectives follow the noun they modify. E.g., sendagille onaren liburu eder au "this beautiful book of the good doctor" (on "good", liburu "book", eder "beautiful", au "this").

When a noun phrase consisting of several parts is modified by a postposition, this postposition is not distributed over the various parts, but attaches only to the last item of the phrase.

Hence: sendagille ona "the good doctor", sendagille onari "to the good doctor"; liburu gorri ederraren jabeari "to the owner (jabe) of the beautiful red (gorri) book".

\subsection{Ergativity}

dator is the $3^{\text {rd }}$ pers. sg. present tense form of the intransitive verb etorri "to come"; dakar is the $3^{\text {rd }}$ pers. sg. present form of the transitive verb ekarri "to bring".

Compare now sentences (1)a, (1)b and (1)c:

(1)a Sendagillea dator. "The doctor is coming."

(1)b Sendagillea dakar. "He (she, it) is bringing the doctor."

(1)c Sendagilleak dakar. "The doctor is bringing it (him, her)."

The noun phrase sendagillea in the unmarked case is subject in the intransitive sentence (1)a. The same form, however, when used in a transitive sentence, is interpreted as the direct object of the verb. To make it a subject, as in (1)c, it needs a special case marker $k$. This special case, used only for the subject of a transitive verb, is called the "ergative". In contrast to it, the unmarked case is called the "absolutive". From a morphological point of view, we do not find in Basque a contrast between a "subject case" (nominative) and an "object case" (accusative), but rather between an absolutive case and an ergative case. This holds true in Basque in all tenses and moods of the verb, and applies to nouns as well as to pronouns. Accordingly, Basque is called a fully ergative language.

However, there is more to a language than just its morphology. There is a whole realm of grammatical phenomena named syntactic processes, whose connection with morphological categories cannot be taken for granted without investigation. And when we do investigate these processes, it turns out that in most of the ergative languages studied, the notion of subject in the classical sense must be recognized, and, in fact, all but totally eclipses the notion of absolutive, which is, at best, of marginal importance in the syntactic functioning of those languages. There are exceptions such as some ergative languages of Australia (e.g. Dyirbal described by Dixon 1972), but they are a small minority. Basque is no exception. At least the following syntactic processes are found in Basque and involve the category of subject: Equi-NP Deletion, Subject Raising, the interplay of Conjoining and Pronominalization, Reflexivization and Reciprocalization. Note that it does not matter whether we describe the distribution of reflexives and reciprocals by means of 
transformational rules or by invoking interpretive mechanisms. In either case, the category of subject will play a crucial role in the description.

Demonstrating this for the rules I just mentioned would require too much space to be attempted here. The interested reader is adviced at this point to turn to a quite interesting and lucidly written exposition by Stephen Anderson: "On the Notion of Subject in Ergative Languages" (Anderson 1976). This author discusses syntactic rules of various ergative languages, and includes a two page discussion of Equi-NP Deletion in Basque. I may add that, having long since repudiated my unpublished paper of 1966 Redefining the Ergative mentioned by Anderson, I find myself in complete agreement with his conclusions.

Bollenbacher (1977) criticises Anderson's views. This criticism, however, is marred by faulty data and must be discarded in toto. To mention just one important point, contrary to Bollenbacher's claims, there is no Passive rule in Basque, and hence no Passive marker $k$. There is a resultative "Passive": umea gizonak arrapatua da "the child has been (not: was) caught by the man" (never: gizonak umea arrapatua da), derived from a bi-clausal source by means of Relative Clause Reduction, as Bouda (1973: 27) and, no doubt, many others too, have recognized.

A few more words to conclude our discussion on ergativity. We saw that, in spite or the ergative morphology, we are forced to recognize the syntactic relevance of the classical notion of subject in Basque. This, it is fair to warn, does not imply that we also accept a base rule of the form $S \rightarrow N P+V P$, which, in the more orthodox versions of generative grammar, formally defines the notion of subject. Whether or not such a rule operates in English syntax is a question I would rather leave open. But this traditional subject predicate dichotomy is much too coarse to accomodate the subtle workings of Basque syntax. This insight, indeed, will be an interesting by-product of our treatment of focus in section 4 of this paper.

\subsection{More on the Structure of the Verb}

Simple conjugated verb forms, such as dator and dakar in sentencies (1)abc, are possible for not much more than a dozen verbs. In our later examples, we will still meet the verbs jakin "to know" and irudi "to seem", with simple forms such as daki "he (she) knows", dakite "they know", dakit "I know", dirudi "he (she, it) seems, dirudite "they seem".

All verbs (with one or two exceptions) admit a periphrastic conjugation, made up of a participle and an auxiliary verb form. There are three participles: an imperfect participle ending in -ten or -tzen, a perfect participle identical with the citation form of the verb, and a future participle ending in -ko (or -go after $n$, as in emango, from the verb eman "to give"). The auxiliary verb indicates tense and mood. In positive sentences the auxiliary follows the participle; in negative sentences the auxiliary precedes, at least, in main clauses. With the intransive auxiliary verb form $d a$ "is" (also used as a copula), we can have:

(2) Sendagillea gutxitan etortzen da.

(2)b Jabea etorri da.

(2)c Umea etorriko da.

"The doctor comes seldom".

"The owner has come."

"The child will come." 
With the transitive auxiliary verb form $d u$ "has" (also used to express possession), we can have:

(3)a Sendagilleak ekartzen du.

"The doctor brings it."

(3)b Jabeak ekarri du.

"The owner has brought it."

(3)c Umeak ekarriko du.

"The child will bring it."

The morpheme eq "no, not" takes care of negation. In the presence of a finite verb, it obligatorily turns into a proclitic, and its final voiceless sibilant influences the pronunciation of the following consonant. The spelling may or may not indicate this fact:

(4)a Umea eztator.

(4)b Sendagillea ezta beti etortzen.

(4)c Jabea ez da etorri.

\begin{abstract}
"The child is no coming."
"The doctor does not always come."

"The owner has not come."
\end{abstract}

During our discussion on ergativity, many a reader will have wondered wheter there is a rule of Verb Agreement in Basque, and, if so, what kind of noun phrase a verb agrees with. This question is answered easily enough. There is an obligatory rule of agreement in person and number. Any finite verb simultaneously agrees with its subject (with morphological differences according to the subject being absolutive or ergative), with its direct object, and with its indirect object.

In just those syntactic functions, unemphatic personal pronouns are not preserved in the surface form of the sentence. Agreement takes place regardless. It applies to nouns and pronouns alike, whether overtly expressed or not. As this paper does not deal with morphological details, a few examples will do to illustrate all this:

(5)a Ume batek liburu bat ekarriko du. "A child will bring a book."

(5)b Bi umek liburu bat ekarriko dute. "Two children will bring a book."

(5)c Ume batek bi liburu ekarriko ditu. "A child will bring two books."

(5)d Bi umek bi liburu ekarriko dituzte. "Two children will bring two books."

(Note: ume bat "one child, a child", bi ume "two children", bi umeak "the two children" as the article $a$ has the plural form $a k$ )

(6)a Jabeak umeari bi liburu ekarriko dizkio. "The owner will bring the child two books."

(6)b Jabeak umeai bi liburu ekarriko dizkie.

"The owner will bring the children two books."

(6)c Jabeak bi liburu ekarriko dizkizu.

"The owner will bring you two books."

(7)a Jabeak eztakarkio liburua umeari.

"The owner is not bringing the book to the child."

(7)b Jabeak eztakarkio liburua. "The owner is not bringing the book to him." 
(7)c Jabeak eztakarkio.

(7)d Eztakarkio.

(7)e Eztakar.
"The owner is not bringing it to him."

"He is not bringing it to him."

"He is not bringing it."

\subsection{Subordinate Clauses and Complementizers}

Given the limited purposes of this paper, we need not bother about non-finite complement clauses and nominalizations, important though they are in Basque syntax. Finite complement clauses, on the contrary, will play an essential role in the discussion. In those, a complementizer suffix is always added to the subordinate verb. Two basic complementizers will appear in the examples. Embedded questions, with or without a Wh question word, are characterized by the Wh complementizer $-n$. With the Wh question word nor "who", we have:
(8)a Nor il da?
"Who died?"
(8)b Eztakit nor il dan.
"I don't know who died."
(8)c Eztakit il dan.
"I don't know if he died."

The unmarked complementizer, corresponding to English that, is the suffix -la:

(9)a Il dala diot.

"I am saying that he died."

(9)b Il dala uste det.

"I think that he died."

(9)c Il dala dirudi.

"It seems that he died."

When the main clause is negative or interrogative, instead of la, nik may be used:

(10)a Ez diot il danik.

"I am not saying that he died."

(10)b Ez det uste il danik.

"I don't think that he died."

(10)c Ez dirudi il danik.

"It doesn't seem that he died."

The governing main verb may precede or follow the complement clause and need not be contiguous to it. Often, the subordinate clause preceeds when the main verb is positive, and follows when it is negative. But this is not a hard and fast rule, as considerations of focus and length or complexity of the various constituents figure heavily in determining superficial word order.

In the next section, I will argue that Basque is underlyingly a verb final language. As complementizers are invariably added to the subordinate verb, it is reasonable to assume that Basque has clause final complementizers, i.e. that there is a base rule of the form $\bar{S} \rightarrow S+$ Comp.

\section{Section 2. The Order of Major Sentence Constituents}

In intransitive sentences, the subject (in the absolutive case) may either precede or follow the verb: 
(11)a Sendagillea atzo il zan.

"The doctor died yesterday."

(11)b Atzo il zan sendagillea.

"The doctor died yesterday."

In these examples, the main verb is $i l$ "to die", "to kill", zan is the 3rd pers. sing. past intransitive auxiliary, and atzo is an adverb meaning "yesterday".

In transitive sentences, both the subject (in the ergative case) and the object (in the absolutive case) may either precede or follow the verb. The order between subject and object also being free, this results in a total of six possibilities.

One example will do to illustrate this. The English sentence (12) a doctor killed two dogs right bere yesterday can be rendered into Basque in a number of ways differing only in word order.

The major constituents will be: sendagille batek "a doctor" (ergative), bi txakur "two dogs" (absolutive), il zituen "killed", where qituen is transitive past auxiliary indicating 3 rd pers. sing. subject and 3rd pers. plur. object. Among the possible translations of (12) are the following:

(12)a Sendagille batek bi txakur ementxe il zituen atzo.

(12)b Sendagille batek ementxe il zituen bi txakur atzo.

(12)c Bi txakur ementxe il zituen sendagille batek atzo.

(12)d Bi txakur sendagille batek ementxe il zituen atzo.

(12)e Ementxe il zituen sendagille batek bi txakur atzo.

(12)f Ementxe il zituen bi txakur sendagille batek atzo.

All of these versions are fully grammatical and acceptable. The adverbs ementxe "right here" and atzo "yesterday" too can take various positions in the sentence. We have kept them in a fixed position, as their behavior is of no interest at this point.

The statistical predominant order is that of (12)a: (1) Subject, (2) Object, (3) Verb. This order is about as frequent as the other five taken together (De Rijk 1969: 321-5 [included in this volume]).

Greenberg (1963), tabulates Basque as a non-rigid type III language, that is, as a language with dominant (but not exclusive) order Subject Object Verb. Furthermore, Basque obeys the three generalizations Greenberg states about type III languages: it is postpositional, it lacks obligatory Wh-preposing, and the auxiliary follows the main verb (at least in positive sentences). For a discussion of these points, see De Rijk (1969: 325-35).

Can we go further and maintain that there is only one deep structure order in Basque: Subject Object Verb? To be sure, to date there is no incontrovertible proof for this. Nonetheless, I am very much inclined to believe that Basque really is verb final in deep structure. With the exception of imperatives (in which an object normally follows the verb), there are no constructions where verb final order is excluded, and there are some where it is required, as, e.g. in relative clauses with lexical heads. This fact alone, it seems to me, strongly speaks in favor of an underlying verb final order. Note also that relative clauses in Basque always precede their heads, as they should do in a verb-final language. (For a detailed discussion of relative clauses in Basque, see De Rijk 1972 [included in this volume]). 
While I have assumed an underlying Subject Object Verb order throughout this paper, none of its conclusions have to be modified if this assumption is not made. In particular, the theory arrived at in section 4 about focus and the structure of the verb phrase is quite independent of it.

\section{Section 3. Topic Fronting}

In this section, we establish the existence of a syntactic rule of topic fronting in Basque and study some of its properties.

In a simple sentence, sentence-initial position of any one constituent may be due to a possible scrambling process to be made responsible for the vicissitudes of surface word order. But when we find examples where a constituent has been moved out of a subordinate clause into initial position in the main clause, there can be no doubt as to the existence of a special fronting rule. Such examples will be presented below.

The constituent to be moved will be sendagille ori "that doctor". In our examples, the $a$ sentences show the original position of this constituent inside the subordinate clause. The $b$ sentences demonstrate the movement to the front of the main clause. Note that the moved constituent keeps whatever postposition it had in the subordinate clause, so that its original grammatical function is still recoverable. We therefore find the forms: orrek (ergative), orri (dative), orrentzat (benefactive), orrekin (sociative), orrengatile (causal) as oblique forms of the demonstrative adjective (and pronoun) ori "that".

This is not the place to enter into the intricacies of the verbal system. Suffice it to say that the main verbs in the examples will be: uste $d u$ "(he) thinks", eq daki "(he) doesn't know", iruditu zait "(it) has seemed (to me)", bildur naiz "(I) am afraid", ez det uste "(I) don't think", ba al dakizu "do (you) know".

We recall from section 1.4. that the verb of the subordinate clause (da "(he) is", egingo $d u$ "(he) will do", bildur diote "(they are afraid (of him)", ez dago "there is not", joango naiz "(I) will go") is provided with a complementizer suffix -n, -la or -nik. This complementizer, of course, is still present after fronting has applied.

(13)a Nere anaiak uste du sendagille ori oso ona dala. "My brother thinks that doctor is very good."

(13)b Sendagille ori, nere anaiak uste du oso ona dala. "That doctor, my brother thinks is very good."

(14)a Iñork ez daki sendagille orrek zer egingo duen. "Nobody knows what that doctor will do."

(14)b Sendagille orrek, iñork ez daki zer egingo duen. "That doctor, nobody knows what (he) will do."

(15)a Askotan iruditu zait sendagille orri danak bildur diotela. "It has often seemed to me that everybody is afraid of that doctor."

(15)b Sendagille orri, askotan iruditu zait danak bildur diotela. "Of that doctor, it has often seemed to me that everybody is afraid." 
(16)a Bildur naiz sendagille orrentzat emen lanik ez ote dagoen. "I am afraid that there may be no work for that doctor here."

(16)b Sendagille orrentzat, bildur naiz emen lanik ez ote dagoen. "For that doctor, I am afraid that there may be no work here."

(17)a Ez dut uste sendagille orrekin, beintzat, iñoiz mendira joango naizenik. "I don't think that I will ever go to the mountains with that doctor, at least."

(17)b Sendagille orrekin, beintzat, ez det uste iñoiz mendira joango naizenik. "With that doctor, at least, I don't think that I will ever go to the mountains."

(18)a $\mathrm{Ba}$ al dakizu sendagille orrengatik nor il dan? "Do you know who died because of that doctor?"

(18)b Sendagille orrengatik, ba al dakizu nor il dan? "Because of that doctor, do you know who died?"

Such instances of topic fronting out of subordinate clauses can be found in Basque literature from the oldest texts on. We will give two examples. From Axular's work Gero, first published in Bordeaux in 1643, we can cite (Villasante's edition, Barcelona 1964: 219):

(19) Ethorkizunekoa eztakigu emanen zaikunz.

"That (i.e. the time) of the future, we don't know if (it) will be given us."

The next example is taken from Tartas book Onsa biltzeko bidia, which was first published in Orthez in 1666. We quote it here according to Eguskitza's edition (Oñate, 1975) p. 7:

(20) Ene euskara, eta lengajia eztakit aprobatia izanen denéz, bai ala ez...

"My Basque and my way of speaking, I don't know if (it) will be approved of, yes or no..."

Sentences (19) and (20) do not belong to the Guipuzcoan dialect. The ending ez in dénez which $z$ in raikun $z$ is a variant of, is typical of indirect questions in the Northern dialects. The form den corresponds to dan in Guipuzcoan.

The rule of Topic Fronting should not be thought of as a kind of Left Dislocation. Left Dislocation is a rule in the grammar of English (and many other European languages) responsible for such sentences as That doctor, $I$ don't think $I$ would like bim to treat me.

Left Dislocation always leaves a pronoun behind. In Basque, however, this is quite impossible:

(21) Sendagille orrekin, beintzat, ez det uste berarekin iñoiz mendira joango naizenik.

To appreciate the force of this counter-example, we must keep in mind that, although there is a rule for deleting unstressed pronouns in the absolutive, ergative 
or dative case, no such rule applies to the sociative case: berarekin "with him" ought to stay in the surface structure, if at all present in an underlying structure.

Another important difference is that Topic Fronting can apply to indefinite noun phrases, whereas Left Dislocation never does. To show this, we make use of the partitive noun phrase sendagillerik "any doctor(s)". In De Rijk (1972a), I showed that partitive noun phrases are necessarily indefinite. Yet they can undergo Topic Fronting:

(22)a Ez det uste sendagillerik iñoiz bearko dedanik.

"I don't think that I'll ever need any doctor."

(22)b Sendagillerik, ez det uste iñoiz bearko dedanik. "Any doctor, I don't think that I'll ever neeed."

Topic Fronting may raise a noun phrase out of several embeddings. In that event, the intermediate stages are grammatical too:

(23)a Ez det uste iñork esango duenik sendagille ori oso ona dala.

"I don't think anybody will say that doctor is very good."

(23)b Ez det uste, sendagille ori, iñork esango duenik oso ona dala.

"I don't think, that doctor, anybody will say that (he) is very good."

(23)c Sendagille ori, ez det uste iñork esango duenik oso ona dala.

"That doctor, I don't think that any body will say that (he) is very good."

To make sure topic Fronting has applied here and not Focus Positioning (to be explained in section 4), we will add the word beintzat "at least" after sendagille or in sentence (23)c. This will exclude focus interpretation on the preceding noun phrase.

(23)d Sendagille ori, beintzat, ez det uste iñork esango duenik oso ona dala.

"That doctor, at least, I don't think anybody will say that (he) is very good."

So far, we have argued the existence of a transformational rule fronting noun phrases. Calling it Topic Fronting, however, implies more. Is suggests that the noun phrase so fronted is invariably the topic of the sentence as a whole.

This now, in Basque, is clearly the case. It is the reality referred to by this noun phrase that the sentence is truly about. It is what has been called "psychological subject" or "theme" in some grammatical traditions. In declarative sentences, the remainder of the sentence can be viewed as a comment on the given topic. The topic quite. often is the same in two adjacent utterances of a connected discourse. Accordingly, we often find it in pronominal form. In Basque, in the absolutive, ergative or dative case functions it will then be deleted. If it is a new topic, however, or a contrastive topic, it will not be deleted even in those functions.

The notion of topic is bound up with the intention of the speaker, as it can be loosely characterized as that noun phrase in an utterance that refers, at least approximately, to what the speaker means to talk about at the moment of his utterance.

Defined in this way, a topic noun phrase need not stand at the beginning of a sentence in Basque. It can occur in almost any position in the sentence, with the 
probable exception of some syntactic island positions in the sense of J. R. Ross. Such a topic need not be marked in Basque by any particular syntactic device, and its topichood is discoverable, if at all, only by the context of discourse or by nonlinguistic factors of the actual speech situation.

Yet, a speaker has the option of overtly marking topichood by shifting the topic noun phrase to the front of the sentence, that is, by applying Topic Fronting. Noun phrases to which Topic Fronting has applied, we will call henceforth "emphatic topics". Topic Fronting is possible even when the topic noun phrase is already in front of the sentence, since this transformation, as we will see later on, lifts the noun phrase out of the sentence, raising it above its original clause. Thus, emphatic topics are always raised topics. This, of course, results in intonational differences between an unmarked initial topic and an emphatic initial topic. The writing system usually signals these differences by putting a comma after an emphatic topic, but not after an unmarked initial topic, unless the latter is rather long or complex.

Basque grammarians, as a rule, do not talk about topic. Yet Altube (1929: 21) states that the first constituent of a sentence should be one that provides a link (eslabón) uniting it with the inmediately preceding sentences. In the one example he adduces, this link happens to be the topic. This, however, is by no means always the case. Non-topical elements, such as ala "in that way", orrengatik "therefore", beraz "so" and many others, can also act as initial linking elements. In that event, the topic may occur later on in the sentence.

Perhaps the reader will have wondered how an indefinite noun phrase like sendagillerik "any doctor" in (22)b can function as a topic, as we claim it does. It is precisely the notion of topic, however, that accounts for the particular shade of meaning conveyed by the word order of (22)b, which can be expressed in English by the paraphrase: Talking about the class of doctors, I don't think I will ever need any.

Continuing our discussion of topic Fronting, when the topic changes from one sentence to the next, the new topic is often emphatic in its first occurrence. We will illustrate this obervation by citing the last paragraph of a folktale published by J. M. de Barandiarán in his work El mundo en la mente popular vasca (III, p. 77). It is a tale that Doña María de Ayerbe, the mother of this illustrious ethnologist, told him around the year 1900. The orthography of the original, which we have kept, indicates the local pronunciation of Ataun (Guipuzcoa). In the English version of sentences (ii) and (iii) the word order has been partly adapted to that of the Basque original.

(i) Geo erregêri agertu ementzion zertan bê alabak oñetakôk urratzen zittûn.

"The he (i.e. the little cobbler) disclosed to the king what his daughter had been getting her footgear torn by."

(ii) $\mathrm{Da}$ alaba oi, plazên erdiñ erre ementzoên.

"And that daughter, in the middle of the marketplace they burnt."

(iii) Zapataitxikîri beiz erregek abeastasun aundîk ema' ementziotzan.

"To the little cobbler, on the other hand, the king gave great riches."

Those are consecutive sentences at the end of the folktale, which closes directly after (iii) with the ritual formula oi ala bazan, sartu deilla kalabazan ("if it was so, let it go into the pumpkin"). The sentences in the tale directly preceding (i) are all about 
the little cobbler. Sentence (i) is too, but its topic, having been pronominalized, is not overtly expressed in the surface form of the sentence.

In sentence (ii) there is no question of the cobbler. Its topic is alaba oi "that daughter". It is marked as such by the pause following it, indicated by the comma. As there is only one clause present, the comma in this position can have no other function than that of indicating topichood rather than mere subjecthood.

In sentence (iii) reversal is made to the former topic zapataitxik $\hat{\imath}$ "the little cobbler". This reversal is signalled in two ways. First, the topic is emphasized by Topic Fronting, as its occurrence before the ergative subject errege "king" is anormal. Second, the particle beiz (usually written berriz) whose literal meaning is "again" serves to make clear that a former topic is reintroduced, and hence that a change of topic has taken place.

Before ending this section we ought to offer at least a few remarks on account of the derived structure of sentences where Topic Fronting has applied.

As we do not countenance discontinuous constituents, it is clear that the moved noun phrase no longer belongs to the lower clause. Native speakers, however, strongly insist that the fronted noun phrase does not become a clause mate of the main verb. Intonational facts too speak against that. An emphasized topic seems to require a distinct pause behind it, indicated in writing by a comma. The topic itself may show an intonation of suspense, with its last syllable being drawn out on a sharply rising pitch.

None of this is odd, however, if only we accept Langacker's (1974: 642) proposal that fronting always involves raising. In other words, all we have to do is to stipulate that what Topic Fronting actually does, is to Chomsky-adjoin the topic to the main clause. In that way, the presence of a major syntactic break after the fronted topic will be fully accounted for.

Some tranformational grammarians might not allow transformations to build structure in this way. We should therefore point out that it is not necessary to assume that the higher clause we need is actually built by the rule of Topic Fronting. Indeed, provided we grant the validity of some syntactic version of the Performative Analysis, the appropriate higher clause is already there waiting for us. In deep structure there will be a performative clause on top of the sentence S:

I DECLARE to you about $\Delta$ that $S$.

or

I ASK of you about $\Delta$ whether $\mathrm{S}$.

or something similar according to the type of speech act involved.

Now, the processes that account for the erasure of the performative clause from surface structure will fail to delete $\Delta$ just in case it has been lexically filled by our rule of Topic Fronting.

In some languages, e.g. in those that $\mathrm{Li}$ and Thompson (1976) call "Topic-Prominent", the topic may occur as such in surface structure in a position in front of the sentence proper. The topic noun phrase is either provided with a special topic marker (as e.g. in Lisu), or else, is unmarked. In Basque, however, we obser- 
ved that the topic occurs with a case marking that varies with its syntactic function. Thus even in case there should be a fixed topic position for emphatic topics in Basque, at least the case marking of the noun phrase appearing there must be adjusted by transformational means. That is, we still need a rule analogous to Topic Fronting.

Lastly, Topic Fronting appears to be a fairly late postcyclic rule. Yet, there are grammatical processes that follow it. Generally, an emphasized topic is the absolute first noun phrase in a sentence. However, native speakers I have consulted do not reject sentences where a Time or Place adverbial precedes a topicalized noun phrase. Some examples are:

(24) Lengo urteetan ere, sendagille orrek, bere erritarrak uste dute jende asko luxperatu zuela.

"In former years too, that doctor, his fellow-citizens believe that (he) buried many people."

(25) Bere gaztedenboran, Ameriketan, sendagille orrek, ia iñork ez daki zer gaiztakeri egin zuen.

"In his youth, in America, that doctor, almost nobody knows what a horrible thing he did."

(26) Orain dala urte asko, sendagille orrek, askori iruditzen zaie bere emaztea il zuela.

"Many years ago, that doctor, it seems to many people that he killled his wife."

Examples such as these I take as an indication that Topic Fronting can still be followed by some of the rules distributing adverbial modifiers over the sentence. In Basque, the position of adverbials of Time and Place is quite free, as long as they are not in focus. (See Section 4).

Note that in the examples given the adverbials all belong semantically to the lower clause. Just like the emphatic topic, they are felt not to be simply clause mates of the main verb. For that reason, what I consider to be the main clause is sometimes viewed as merely an insert of qualifying material into the main clause all the other sentence constituents are then said to belong to.

Whatever psycholinguistic plausibility this idea may possess, it can hardly be accepted by the analyst of grammatical structure. The alleged insert has all the properties of a main clause, and, even more to the point, the obligatory presence of the complementizer suffix on what is alleged to be the main verb, argues against any such analysis.

\section{Section 4. Focus and the Structure of the Verb Phrase}

Considerably more important in Basque syntax than the notion of topic is that of focus. To explain this concept and show its relevance to Basque grammar, let us start by looking at a fairly simple English sentence: 
(27) Xaviera will take Virginia to Reno tomorrow.

To be able to translate (27) into Basque, we have to know more about its meaning that can be inferred from the written form of the sentence in isolation. We must know what particular inquiry motivates the utterance. In more precise terms, we must know just what informational gap on the part of the audience the speaker is trying to fill. Sometimes, the object of inquiry is inferrable from the preceding discourse, especially when the sentence is uttered by way of answer to an actual question. At other times, contextual information is insufficient to predict what the point of the utterance will be. Now, in Basque, the object of inquiry, present in the mind of the speaker, will determine the surface form of the sentence with regard to word order. If the implicit question is: Who will take Virginia to Reno tomorrow? (27) will be translated as (27)a:

(27)a Xavierak eramango du Virginia Renora biar.

If the implicit question is: Who will Xaviera take to Reno tomorrow? (27) will be translated as (27)b:

(27)b Xavierak Virginia eramango du Renora biar.

If the implicit question is: Where will Xaviera take Virginia to tomorrow? (27) will be translated as (27)c:

(27)c Xavierak Renora eramango du Virginia biar.

If the implicit question is: When will Xaviera take Virginia to Reno? (27) will be translated as $(27) \mathrm{d}$ :

(27)d Xavierak biar eramango du Virginia Renora.

Focus can now be defined as that constituent of an utterance that corresponds to the question word in the associated question. Thus, in (27)a Xavierak is focus, in (27)b Virginia, in (27)c Renora and in (27)d biar. It follows from this definition that the focussed noun phrase is presented by the speaker as contributing totally new information. One should not make the assumption, however, that the other noun phrases in the sentence necessarily deal with old information. In (27)b e.g., where Virginia is focus, the other constituents, the time adverb biar among others, need not be presupposed. The question defining focus, then, should not be as detailed as we have just made out. It could have been just as well: Who will Xaviera take somewhere sometime? In fact, even an excessively vague question like: Who will someone take somewhere sometime? would still be firm enough a basis to establish Virginia as focus in (27). In short, the semantic import of focus is that the focussed constituent is presented by the speaker as being the relatively most important piece of new information given in the utterance.

Sentence (27) may be uttered as an answer to still other questions. E.G.: What will Xaviera do about Virginia going to Reno tomorrow? In that case, the verb will be focus, and the Basque translation will have eraman egingo du, "take will do" instead of eramango $d u$ "will take". Or the associated question may be: Will Xaviera take Virginia 
to Reno tomorrow, or won't she? In that case, the sentence modality (its truth-value, so to speak) is focussed on, and no special word order is required.

The various possibilities for focus and its manifestations in surface grammar are extensively discussed by Altube (1920, and 1929). See also De Rijk (1969: 342 ff) and Donzeaud (1972). For our present purposes, however, it will be sufficient to consider those cases where the focus consists of a noun phrase.

Since we subsume postpositional phrases under noun phrases, most adverbials will also be noun phrases. Moreover, in accordance with the guidelines laid down by the editor, we will limit our considerations to positive declarative sentences.

We now return to our examples (27)a, b, c, d. As the order of constituents in each of the examples is not the only one consistent with the intended focus, we still have to make clear just what the syntactic correlate of the semantic notion of focus consists of. It is simply this: Whatever constituent is focus must immediately precede the verb.

The verb in all the examples is eramango $d u$ "(she) will take (her)".

In (27)a Xavierak is focus, and we have: Xavierak eramango du...

In (27)d Virginia is focus, and we have: Virginia eramango du...

In (27)c Renora is focus, and we have:... Renora eramango du...

In (27)d biar is focus, and we have: ...biar eramango du...

The same rule also applies to interrogative words (wh-items) in questions. They too must immediately precede the verb. In fact, we will widen the scope of our definition of focus to include all wh-constituents. In view of the way focus is defined, this seems quite a natural extension of the concept. Naturally, we do not preclude the possibility that wh-constituents may have additional properties over and above those they share with other focus constituents.

So far, the focus in our examples has been one single constituent. As a matter of fact, Basque grammarians generally conceive of focus in that strain. Yet, it may happen that the implicit question associated with an utterance contains more than one interrogative word. If so, the utterance will have a focus consisting of more than one constituent. As an example, let us consider (28):

(28) Maiburuak ezpatadantzariari lenengo saria eman dio.

"The chairman has given the sword-dancer the first prize."

One possible way of interpreting (28) is to think of it as a partial answer to the question: Which prize has the chairman given to whom? In that interpretation, both expatadantzariari "to the sworddancer" and lenengo saria "the first prize" will be focus, but not maiburuak "the chairman".

Professor Jose Basterrechea, well known for his thorough study of intonation (bound up with focus) in his native Guernican Basque (see Basterrechea 1974, 1975), has confirmed this in a letter to the author, describing also the intonation pattern of (28) typical of that interpretation. It thus turns out that multiple focus is possible, even though it may be somewhat rare in practice.

There are several ways in which one might account for the facts of focus as far as word order is concerned. One way would be to add an output constraint on Scrambling. A sentence will be thrown out as ungrammatical, unless, after Scrambling, the focussed constituents end up directly in front of the verb. 
One might also go at it the other way. Rather than having focus determine word order, we could let word order determine focus. We could set up interpretive rules assigning focus on the basis of word order and the presence or absence of certain morphemes. This is the solution sketched by Donzeaud (1972) in section 5 of her paper.

Now, I do not wish to delve into arcane controversies as to the organization of grammar or the directionality of rules. Rather, I want to bring out the true significance of focus phenomena in Basque, while keeping the account as simple and straightforward as possible. Accordingly, my approach will be to assume that noun phrases can be marked by a syntactic feature Focus in underlying structures. At some stage in the derivation, a movement rule, called Focus Positioning, will apply and put noun phrases marked + Focus in front of the verb.

Focus Positioning is a close analogon to Wh-Movement in English. The status of the feature Focus is quite comparable to that of $W b$ in English, and both rules move marked noun phrases into preverbal position. But the different location of the verb in these languages obscures the similarity between the rules. In English, preverbal position happens to coincide with sentence-initial position. In Basque, this is not so. Therefore, Focus Positioning, unlike Wh-Movement, cannot be though of as a fronting rule. In fact, if my assumption of verb final order in Basque is correct, Focus Positioning will usually involve rightward movement.

Interesting though it may be, Focus Positioning is only half the story. A fact that so far seems to have escaped everybody's attention, is that focus in Basque is not just a matter of word order, but also, and primarily, a matter of constituent structure.

The argument for showing this runs as follows. Our exposition has made clear that it is impossible to insert any constituent susceptible of bearing focus between a focussed noun phrase and the verb, without thereby a change in focus taking place.

Nothing we have said, however, accounts for the fact that it is impossible to insert anything at all between a focussed nominal and the following verb. Consider, for instance, the following sentence adverbials: noski "of course"; beintzat, beiñipein, bederen, all meaning "at least"; batez ere, batipat, both meaning "expecially"; alaere "for all that"; gaiñera "moreover"; alegia "surely"; bada "well eh".

In general, the items of this list, when semantically appropriate can be freely intercalated between most of the constituents of a Basque sentence. But, although they cannot possibly bear focus, these items cannot be intercalated between the focus and the verb.

There is a short list of items that can be intercalated between the focus and a simple finite verb form. They are: eq "not", omen "reportedly", bide "apparently", ote "by any chance", and al, a yes-no-question marker. If the verb form is periphrastic, these elements always appear in front of the auxiliary, never in front of the participle. As I showed in De Rijk (1972a: 131-132), they are proclitics to the finite verb, and hence will end up dominated by V. Becoming thus part of the verb itself, they do not constitue counter-examples to the claim I am here making.

The examples below will demonstrate the imperviousness of the focus verb combination. Candidates for insertion will be the extremely common adverbs beintzat "at least" and noski "of course". 
(29)a Txerri oiek zenbat balio duten nik dakit.

"I know what those pigs are worth."

(29)b *Txerri oiek zenbat balio duten nik, beintzat, dakit.

(29)c Txerri oiek zenbat balio duten nik, beintzat, badakit.

"I, at least, know what those pigs are worth."

Example (29)b, the result of inserting beintzat in (29)a, is ungrammatical. While the simple verb form dakit "I know" without the prefix ba requires a nominal focus, the presence of beintrat blocks it. Informants, when confronted with (29)b, will automatically change it to (29)c. The prefix $b a$ on the verb underlines the affirmative character of the utterance: "yes, I knów..." and implies the absence of a nominal focus.

Likewise (30)a, but not (30)b, is a normal answer to question (30):

(30) Aitak gona gorria nori eman dio?

"Who has father given the red skirt to?"

(30)a Aitak gona gorria amari eman dio, noski.

"Father has given the red skirt to mother, of course."

(30)b Aitak gona gorria amari, noski, eman dio.

There is a suffix $x e$, appearing on demonstratives and certain adverbials of time, place and manner, just in case they are in non-contrastive focus. With the demonstrative pronoun ori "that" we get:

(31)a Orixe dakit. "I know thát. (i.e. that's what I already know)."

(31)b *Orixe, noski, dakit.

(31)c *Orixe, beintzat, dakit.

(31)d Ori, noski, badakit. "That, of course, I know."

(31)e Ori, beintzat, badakit. "That, at least, I know."

Not even a pause can be intercalated between the focus and the verb, as the eminent Basque linguist Professor Luis Michelena observes when discussing the intonation of the sentence gaur izan dute "they had it today", where gaur "today" is focus (Michelena 1976: 149).

These facts, it seems to me, can only lead to one conclusion. There is a syntactic constituent $\mathrm{X}$ in surface structure that consists of the nominal focus and the verb. Thus, in (27)a there is a constituent Xavierak eramango du "Xaviera will take (her)"; in (27)b, Virginia eramango $d u$ "(she') will take Virginia"; in (27)c, Renora eramango du "(she) will take (her) to Reno"; and in (27)d, biar eramango du "(she) will take (her) tomorrow".

What kind of constituent is this? What is its category label $\mathrm{X}$ ? To find the answer, let us proceed by elimination. $X$ has none of the properties of a noun 
phrase, hence $X \neq N$. Obviously, $X \neq V$. Surely, putting $X=S$ will not do, our whole point being that $\mathrm{X}$ does not behave like an $\mathrm{S}$ with regard to the insertion of adverbs and interjections. Now, $\mathrm{X}$ is the next higher node above $\mathrm{V}$. Moreover, it also dominates one or more NP's. What else, then, could it be but VP?

Assuming this is correct, the surface structure of a Basque sentence will consist of a VP with several NP's outside of it; not just the subject noun phrase as in the traditional analysis of English or Dutch sentences. In fact, all of the major noun phrases of a Basque sentence may remain outside of VP, as in (32):

(32) Aitak amari gona gorria biar ekarriko dio.

"Father will bring mother the red skirt tomorrow."

Here, the ergative subject aitak "father", the direct object gona gorria "the red skirt", and the indirect object amari "mother" are all outside of the verb phrase biar ekarriko dio "will bring tomorrow". It follows that no phrase structure rule of the form S $\rightarrow \mathrm{NP}+\mathrm{VP}$ defines the notion of grammatical subject in Basque.

We are touching here upon a rather important point of universal grammar. Let us, therefore, elaborate on it a little. As we argued in section 1.2., in both English and Basque sentences have subjects. As we have just shown, in both English and Basque sentences have predicates (i.e. VP's) in surface structure. The essential difference between English and Basque is this: VP in English always seems to function as a unitary predicate, whereas VP in Basque is an $n$-ary predicate, where $n$ can take, at least, the values $0,1,2,3$. In (32), there are three major sentence constituents outside of $\mathrm{VP}$, hence $n=3$. In the sentence ni noa "I'm going" (with $n i$ "I" as focus: It's me who's going.), VP coincides with $\mathrm{S}$, and hence we have $n=0$.

The term "predicate" should not lead to confusion in this context. I use it in the sense of traditional grammar, as a synonym of verb phrase. I am not talking about semantic predicates or verbs in deep structure. On that level, I do not expect to find much divergence between Basque and English. Certainly, both languages have all sorts of semantic predicates, including ternary ones like, say, GIVE. What I am here talking about is the VP and the number of noun phrases it takes to complete the sentence.

Now, quite apart from our treatment of focus as a feature in underlying structure, it is obvious that VP in Basque cannot be taken as a deep structure node, as long as deep structure is defined as a level where underlying grammatical relations are systematically specified. Which NP in a sentence will be dominated by VP cannot be predicted from the grammatical relation it bears to the verb, but only from the semantic concept of focus. In Basque, therefore, VP is a transformationally introduced node.

The initiated, of course, are aware that the Generative Semantics school has regarded VP as a derived node all along. The suggestion repeatedly made in those circles that VP is merely an S that has lost its subject, however, is seen to be quite inadequate in the light of our present discussion.

I would like to propose a transformational rule of Verb Phrase Formation. Its operation will be shown by the following two diagrams, using sentence (32) as an example. 


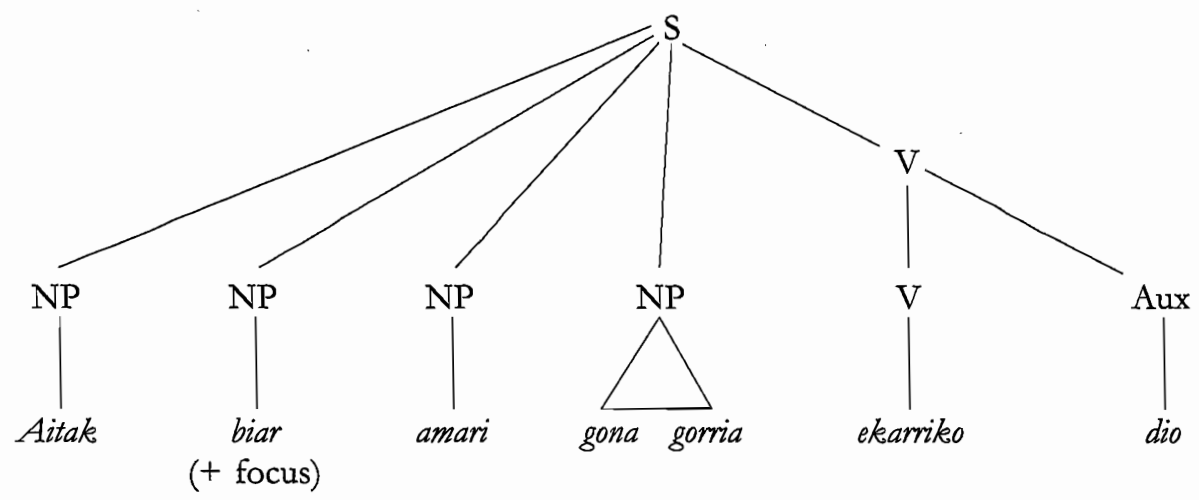

Diagxam 1. Before Focus Positioning

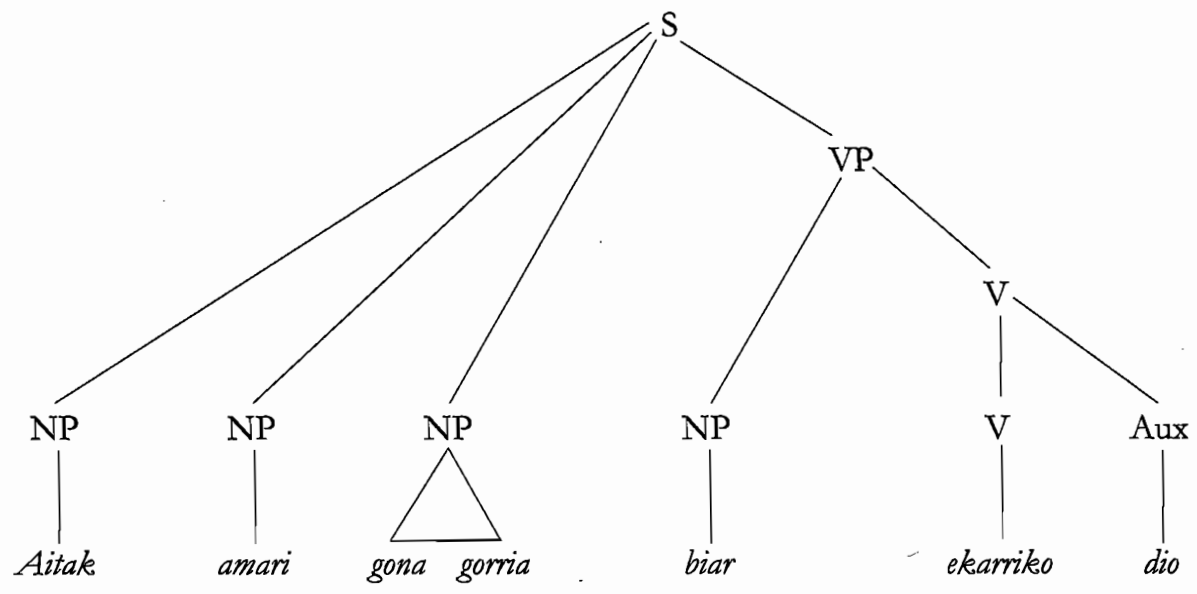

Diagram 2. After Focus Positioning and Verb Phrase Formation

At this point, the reader may ask why Focus Positioning and Verb Phrase Formation have been treated as two separate rules? Why not collapse these two into a single process?

Separating the two components of the process was done for two reasons. One reason was simply ease of exposition. A more important reason was that I do not wish to exclude on the outset the possibility that under highly special circumstances Focus Positioning might take place without being followed by Verb Phrase Formation. It would take up too much space to speculate here on what those circumstances might be.

If the theory set forth here is basically correct, languages may differ widely as to the character of their verb phrases. The question then arises what other aspects of grammatical structure correlate with the occurrence of non-unitary predicates as found in Basque. More precisely, what other characteristics of grammar, present in 
Basque, make it possible for a verb phrase of this nature to emerge? And, vice versa, are there properties in Basque, conditional upon precisely this kind of verb phrase? Just to mention one example, what about the multiple agreement exhibited by the verb in Basque? Can it be shown to be connected in some way with the structure of the predicate?

It seems to me that these important questions constitute an interesting program for future research. Needless to say, the investigations should not be confined to Basque. There are other languages that deal with Focus in a way essentially like Basque. Hungarian, to all appearance, is a case in point.

Research of this kind can be a step on the road to our ultimate goal: the discovery and study of the invariants of linguistic structure underlying the amazing variety of the syntactic systems of the languages of mankind.

\section{References}

Altube, S., De sintaxis euskérica, (1920).

—, Erderismos. Bermeo, (1929) reprinted 1975.

Anderson, S. R., "On the Notion of Subject in Ergative Languages". In Li (1976), pp. 1-24.

Basterrechea, J., "Estudios sobre entonación vasca según el habla de Guernica, I", FLV VI, (1974), 353-393.

_- "Estudios sobre entonación vasca según el habla de Guernica, II", FLV VII, (1975), 289-338.

Bollenbacher, J., “The Basque Passive”. In: Douglas, Etulain and Jacobson, (1977), pp. 181-192.

Bouda, K., "Berichtigungen zu einer Abhandlung über baskische Syntax, FLV V, (1973), 21 36.

Dixon, R. M. V., The Dyirbal Language of North Queensland. Cambridge U.P. (1972).

Donzeaud, F., "The Expression of Focus in Basque", ASJU VI, (1972), 35-45.

Douglas, W. A., Etulain, R. W., Jacobsen, Jr., W. H. (eds), Anglo-American Contributions to Basque Studies: Essays in honor of Jon Bilbao. Desert Research Institute Publications on the Social Sciences no. 13.

Greenberg, J. H., "Some universals of grammar with particular reference to the order of meaningful elements". In: J. H. Greenberg (ed), Universals of Language, pp. 58-90. Cambridge, (Mass) M.I.T. Press.

Langacker, R. W., "Movement Rules in Functional Perspective", Lg 50, (1974), 630-664.

Li, C. N. (ed), Subject and Topic. Academic Press, New York.

and S. A. Thompson, "Subject and Topic: a New Typology of Language". In: Li (ed) (1976), pp. 457-491.

Michelena, L., "Acentuación alto-navarra", FLV VIII, (1976), 147-162.

Rijk, R. P. G. de, "Is Basque an S.O.V. Language?”, FLVI, (1969), 319-351.

- "Relative Clauses in Basque: a Guided Tour". In: Peranteau Levi, Phares (eds). The Chicago Which Hunt, (1972), pp. 115-135.

_ _ "Partitive Assignment in Basque", ASJU VI, (1972a), 130-173. 